\title{
Developing the Life Skills-Based Student Worksheet for Minor Chemical Industries
}

\author{
Devita Cahyani Nugraheny \\ STKIP Kusuma Negara, Bogor Highway KM 24, Cijantung, East Jakarta, Indonesia \\ Email: devitacahyaninugraheny@gmail.com
}

Received: 17 April 2016; Revised: 22 April 2017; Accepted: 8 May 2017

\begin{abstract}
This study aimed at identifying and developing the quality of life skills-based student's worksheet for minor chemical industries. This study was a research and development that referred to the developmental model proposed by Borg \& Gall. The procedures in this study consisted of four stages namely introduction, planning, product design, and product validation. The product validation was conducted by the peer reviewers, the media and material experts and the Chemistry teachers in order to gather assessment and suggestions on the quality of student's worksheet that had been implemented to the Chemistry teachers in SMK N 1 Panjatan. The data gathering instrument that the researchers used was the product validation sheet. The results of this study showed that the product that had been generated was in the form of life skills-based student's worksheet for minor chemical industries. On the other hand, the results of an assessment by the Chemistry teachers showed that in average the student's worksheet fell into the "Very Good" category; as a result, the life skills-based student's worksheet for minor chemical industries is feasible for implementation in the learning process.
\end{abstract}

Keywords: development, student's worksheet, life skills

How to Cite: Nugraheny, D. (2017). Developing the life skills-based student worksheet for minor chemical industries. Jurnal Inovasi Pendidikan IPA, 3(1), 30-41. doi:http://dx.doi.org/10.21831/jipi.v3i1.13689

Permalink/DOI: http://dx.doi.org/10.21831/jipi.v3i1.13689

\section{INTRODUCTION}

Vocational high schools as an important part of vocational education system prepare the students to mainly work in certain domains. The problems in vocational high schools that have been perceived are very important in relation to the vocational high school graduates' incapability to enter the employment. The reason is that the graduates' quality has been far below the market demand (Nurharjadmo, 2008, p. 215). Several facts in the practice show a concerning situation. Based on the results of a study in 2009 , vocational high school graduates have had the greatest percentage of unemployment (Widiaty, 2013, p. 31).

Due to this situation, educational units develop and implement education according to students' conditions, schools' conditions, potentials and regional demands. This development leads to the students' life skills improvement. Life skills should be possessed by individuals so that they will be willing and be encouraged to deal with the life problems normally without having to be depressed. Then, they might be creative and proactive in looking for solutions for overcoming the problems (Harahab, Raharjo, \& Kuswanti, 2012, p. 28). Life skills refer to the capability of performing adaptation and positive behaviors which enables individuals to handle their daily demands and challenges effectively (World Health Organization, 1991 p.1).

The life skills-oriented educational objective in general is developing students' potentials in dealing with their role in the future life. On the contrary, the life skills-oriented educational objectives in specific are: (1) actualizing the students' potentials so that these potentials might be implemented in solving problems; (2) providing schools the opportunities to develop a flexible learning process in accordance to the principles of widebased education; and (3) optimizing the resources in the school environment (Yuliati, Umniyatie, \& Setyaningsih, 2008, p. 177).

Washington State University proposes eight indicators of life skills. The first indicator 
is decision making, which refers to the capabilities of making decisions among various alternatives, of defining alternative lists before making decision, of considering consequences that might appear from the decisions that will be made and of evaluating the selection that has been made. The second indicator is wise use of resources, which refers to the capabilities of using references, of gaining benefits, of displaying values of responsibility and of making decisions based on priorities. The third indicator is communication, which refers to the capabilities of sharing opinions, information or messages with anyone by means of effective conversation, composition, gesture and expression. The fourth indicator is accepting differences, which refers to the capabilities of regulating and accepting discrepancies or differences with anyone. The fifth indicator is leadership, which refers to the capacities of explaining and exerting something to any parties in a group. The sixth indicator is useful/ marketable skills, which refers to the capabilities of working as employment-demanded labors. The seventh indicator is healthy lifestyle choices, which refer to the capabilities of a lifestyle that will be healthy for both body and mind and of avoiding bruises, scratches and diseases. Last but not the least the eighth indicator is self-responsibility, which refers to the capabilities of protecting one's self, of appreciating self behaviors and their impacts, and of selecting the position between the right and the wrong things (Handayani, 2009, pp. 67).

There are generic, specific and vocational life skills. The generic life skills include the personal proficiency which consists of: (1) awareness toward existence; and (b) awareness toward self-potentials. Then, there are also rational-thinking proficiency and social proficiency. The rational thinking proficiency consists of: (a) investigation proficiency; (b) information-processing proficiency; (c) decision-making proficiency; and (d) problemsolving proficiency. On the other hand, the social proficiency consists of: (a) oral communication proficiency; (b) written communication proficiency; and (c) cooperation proficiency. Furthermore, the specific life skills refer to the proficiency in dealing with employment or in dealing with certain situations. The specific life skills include the academic proficiency, which consists of: (a) variable-identifying proficiency; (b) variable-associating proficiency; (c) hypo- thesis-formulating proficiency; and (d) implementation proficiency. Last but not the least, the vocational life skills are related to the job domain that demands motor skills. The vocational proficiency consists of: (a) fundamental vocational proficiency; and (b) specific vocational proficiency (Handayani, 2009, p. 2; Khoiri, Hindarto, \& Sulhadi, 2011, p. 86; Pusat Kurikulum Balitbang Depdiknas, 2006).

Vocational proficiency refers to the skills that are related to certain job domains in the society. Vocational proficiency is more suitable for the students who will enter the employment that prefers the psychomotor skills to the scientific-thinking skills. Therefore, the vocational proficiency is more suitable for the vocational students, the skill course students, or the diploma program students (Handayani, 2009, p. 5).

The implementation of life skills education is integrated to various subjects in all educational types and degress (Menteri Pendidikan Nasional, 2006; Sudira, 2006). Life skills might be integrated into learning objectives, learning activities, and learning media (Harahab et al., 2012, p. 28). Learning media are available in various forms and one of the forms is printed media. The most widely used print-based media is book and it might be guiding book, journal, magazine, and student's working sheet (Arsyad, 2002, p. 87). Based n the statement, the researcher might conclude that print-based learning media might be benefitted as a tool for developing students' life skills.

Based on the above explanation the objectives of conducting learning process in vocational high schools are preparing the students to pursue their independent life, preparing the students to enter employment and preparing students to continue higher education after they have graduated. Students should have good stamina, master their domain of proficiency, master basics of science, master technology, have high working ethos, be able to perform communication in accordance to their employment demands and have self-developing capabilities in order to work effectively and efficiently as well as to develop their skills. The structure of vocational education curriculum, in this regards the vocational high schools and the vocational madrasah aliyah, is directed to achieve those objectives (Sudira, 2006, p. 24). The learning objectives of vocational high schools have been formulated in the Educational Unit Level Curriculum for Vocational High 
Schools. The vocational high schools curriculum contains compulsory subjects, vocational subjects, local-content subjects and selfdevelopment subjects.

The local-content subjects are inserted to the extracurricular activities. The local-content subjects aim at developing the competencies that will be adjusted to the regional peculiarities, regional potentials and regional development prospects including the regional superiorities. The substance of local-content subjects is determined by the educational unit in accordance to the expertise programs that have been designed (Menteri Pendidikan Nasional, 2006).

Based on the results of a survey that had been conducted in SMK N 1 Panjatan, the researcher found that this vocational high school has three domains of expertise namely chemical industry, chemical analysis and chemical pharmacy. The learning process in SMK N 1 Panjatan is supported by the local content subjects that might be benefitted as a tool for developing the students' process, scientific attitudes and life skills. One of the local content subjects that this vocational school has is chemical minor industry.

The chemical minor industry subject provides an opportunity for the student to develop their process, scientific attitudes and life skills through the processing of products that will be useful and that might be applied into the society. The products that are processings include chemical materials, reactions and process such as the ones that might be found in the processing of VCO oil, liquid soap, bar soap, soyabean milk, nata de coco processing and alike.

The development of process skills might be pursued through process of product processing that the students perform. The American Association for the Advancement of Science (AAAS) classifies the scientific process skills into 15 aspects namely observation, measurement, classification, communication, prediction, inference, number use, time and place association use, question, variable control, hypothesis, operational definition, model design, experiment design, and data interpretation. The scientific process skills might be classified into two categories namely the fundamental process skills and the integrated process skills. The fundamental (simple) process skills refer to the basis of learning the integrated (more complex) process. The process skills are very important for concept and science learning in elementary schools and in junior high schools. The integrated process skills are implemented in the senior/vocational high school level and the university level such as the model design, the experiment design and the inference (Akinbobola \& Afolabi, 2010, p. 234). The fundamental process skills and the integrated process skills are appropriate to and might be implemented in Indonesian vocational high schools.

In addition to developing the process skills, the product processing process might also be made as a medium for developing the students' scientific attitude. Scientific attitude is the attitude that a scientist or an academician should have when he or she deals with scientific problems (Anonim, 2010).

There are many experts who classify scientific attitude. Pitafi \& Farooq (2012, p. 283) and Patil (2011, p. 24) stated that scientific attitude might take a form of curiosity, rationalism, open mind, critical thinking, objectivism, honesty, responsibility, modesty, and alike. The National Curriculum Council (1989) stated that the scientific attitudes that are very important to possess in every science educator level are curiosity, reality (facts and data) appreciation, willingness to accept uncertainty, critical and cautious reflection, persistence, tenacity, steadfastness, creativity for new innovation, open mind, sensitivity toward surrounding environment, and cooperation.

The American Association for Advancement of Science emphasizes four attitudes namely honesty, curiosity, open mind and skepticism. This statement is based on the fact that along the history human beings heavily emphasize the transmission on activities of trading values, attitudes, and skills from one generation to another. Family, religion, spouse, books, entertainment media and life expectations in general are the matters that have the greatest influence in shaping view, knowledge, learning, and other life aspects.

The existence of local content subject in the form of minor chemical industry is expected by SMK N 1 Panjatan to encourage the students to processing useful products by benefitting the materials around them. The process of manufacturing those products is conducted through experiment/laboratory practice. In conducting this process, the students are mentored by the student's worksheet. 
The student's worksheet, or also known as LKPD (Lembar Kerja Peserta Didik) serves as one of the learning media because it might be applied altogether with the other learning sources or media (Widjajanti, 2008, p. 1). Student's working sheet is a guideline for the students in performing investigative or problemsolving activities (Trianto, 2010, p. 22). The General Guideline of Learning Material Development reveals that student's working sheet is a sheet containing assignments that the students should accomplish. Worksheet is usually available in the form of guidelines or directions for accomplishing assignments and the assignments should be clear and be in accordance to the basic competencies that will be achieved (Prastowo, 2011, p. 203).

Each student's working sheet is designed with certain materials or assignments that have been designed in such a way that the worksheet will serve certain purposes. The differences between the intentions and the objectives of packaging the materials in each student's working sheet will results in various worksheets. According to Prastowo (2011, pp. 209-211), there are five worksheets that have been generally used namely: (1) the worksheet that assists the students in defining a concept; (2) the worksheet that assists the students in implementing and integrating various concepts that have been found; (3) the worksheet that serves as learning guidelines; (4) the worksheet that has strengthening purpose; and (5) the worksheet that serves as laboratory practice guidelines.

The first type of the worksheet assists students to define a concept. According to the concept of constructivism, an individual will learn if he or she is actively constructing knowledge in his or her brain. One of the ways to implement this theory in the class is through packing the learning materials into the worksheet. This worksheet contains what the students should perform and consists of performance, observation and analysis. The characteristics of this worksheet are proposing concrete phenomena first, are simple, and are related to the concepts that have been studied. Based on their observation, the students are invited to construct the knowledge that they have attained.

The second type of the worksheet assists students in implementing and integrating various concepts that have been found. Within the learning process, each student who has successfully found a concept will be trained to implement the concept that he or she has learned into the daily life. The example of such worksheet is the worksheet that assists students in implementing the concept of democracy into their daily life. The students are assigned to perform discussions and then they are asked to train providing the responsible freedom of speech to other people. By training the students to respect other people' opinion and to perform responsible freedom of speech, the values of democracy might be embedded into the students automatically.

The third type of the worksheet serves as learning guidelines. This type of worksheet contains questions which answers are found in the student's book. The students might answer the questions in this worksheet if they read the student's book. The main function of this worksheet is serving learning participants to understand and to memorize the learning materials that have been written in the student's book. This worksheet is also appropriate for remediation needs.

The fourth type of the worksheet has strengthening purpose. This type of worksheet is provided after students have finished learning certain topics. The learning materials that have been packaged in this worksheet are more directed to the deepening and the implementation of learning materials that are contained in the learning books. This worksheet is also suitable for enrichment.

The fifth type of the worksheet serves as laboratory practice guidelines. This type of worksheet enters the laboratory practice directions into the worksheet. Thereby, the laboratory practice directions become one of the contents in this type of worksheet.

The student's worksheet contains a series of fundamental activities that students should perform in order to maximize their understanding as an effort of shaping the student's fundamental capabilities in accordance to the learning achievement indicators that should be achieved. The worksheet might be in the form of cognitive aspect development learning guidelines or in the form of all learning aspects development that has been packed into laboratory practice guidelines. The components of this worksheet consist of: (1) experiment title; (2) brief theory regarding the learning materials; (3) tools and materials; (4) experiment procedures; (5) observation data; (6) conclusions 


\section{Jurnal Inovasi Pendidikan IPA, 3 (1), 2017 - 34}

Devita Cahyani Nugraheny

and questions for discussion materials (Trianto, 2010, pp. 222-223).

There are several points that should be given attention in designing the worksheet (Devi, Sofiraeni, \& Khairuddin, 2009, pp. 3637). First, in terms of presentation the points that should be given attention are as follows: (1) the title of the worksheet should be in accordance to the materials; (2) the materials should be in accordance to the students' development; (3) the materials should be presented logically and systematically; (4) the materials should be presented in a simple and clear manner; and (5) the materials should support the students' active willingness and participation. Second, in terms of layout the points that should be given attention are as follows: (1) the presentation should be simple, clear, and understandable; (2) the figures and the graphics should be in accordance to the concepts; (3) the placement, the figures, the tables, and the questions should be appropriate; (4) the title, the information and the instructions should be clear; and (5) the layout should develop the students' interest and should invite the students into thinking process.

The student's worksheet should meet various requirements namely didactical requirements, constructional requirements and technical requirements (Rohaeti, Widjajanti, \& Padmaningrum, 2009, p. 3). The didactical requirements regulate the universal use of the worksheet so that the worksheet might be implemented well by all students. The student's worksheet is expected to prioritize the development on the social communication capabilities, the emotional communication capabilities, the morale communication capabilities, and the esthetical communication capabilities as well as to invite the students to be active in the learning process. The constructional requirements, on the other hand, are related to the use of language, sentence composition, vocabulary, difficulty degree, and clarity in the worksheet. Last but not least, the technical requirements emphasize the presentation of the student's worksheet in the form of composition, figure, and appearance.

The objective of using the worksheet within the learning process is to support the mastery of scientific knowledge by the students, the inquiry mastery, and the development of scientific attitudes. The use of the worksheet might also develop the students' interest toward the learning process through discussion and experiment procedures implementation (Toharudin, 2011, p. 16).
Up to date, the practice of product processing in SMK N 1 Panjatan is supported by job sheets that have been very simple. These job sheets only consist of title, objectives, list of tools, list of materials, and procedures. The existing job sheets have not contained the students' life skills development, process skills development and scientific attitude development.

The presence of the worksheet is very useful for the teachers and the students in performing their activities. Based on the results of a survey, it turns out that $16 \%$ teachers in the Province of Yogyakarta Special Region design their own student's worksheet (Yuliati et al., 2008 , p. 175). Based on the results of an interview with the teachers of SMK $\mathrm{N} 1$ Panjatan, the researcher found that this vocational high school has not designed a student's worksheet that might develop the students' life skills, scientific process and scientific attitudes. Therefore, life-skills based-student's worksheet for minor chemical industries should be designed in order that a good student's worksheet might be resulted in order to improve the students' process skills and scientific attitude.

Research and development is one of the ways or the steps for developing a new product or improving an old product and this method is reliable (Sukmadinata, 2013, p. 164). According to Borg \& Gall (1983, p. 772), research and development is a process of developing and validating a product that had been resulted. The products that might be resulted from the research and development activities are namely teacher training material, learning material for students, learning media for assisting the learning process, learning method, learning model, and alike.

This study then, aimed at: (1) developing life skills-based student's worksheet for minor chemical industries; and (2) evaluating the worksheet quality based on the aspects of content, language and graphics.

A study that has been relevant to this study is the one that had been conducted by (Hayat, Anggraeini, \& Redjeki, 2011); in this study, they performed an experiment regarding laboratory practice-based learning for the concept of vertebrate creatures in order to develop the students' scientific attitude. The results of this study showed that laboratory practice learning process has positive impacts and is more effective in developing the students' 
scientific attitude in comparison to the conventional learning process.

Another study was conducted by Widayanto (2011), who performed a class action research regarding the development of understanding and process skills for the $\mathrm{X}$ grade students through optical kit. In his study, he found that the most important factor in developing the understanding and process skills has students' participation in the laboratory practice activities. The results of his study showed that the more the students are involved in the laboratory practice activities the higher the students understanding and process skill will be. Furthermore, Senam, Arianingrum, Permanasari, \& Suharto (2008) performed an experiment regarding the effectiveness of Chemistry learning process XI Grade students that implemented life skills-based Chemistry Student's Worksheet. The results of the study showed that there have been significant differences on the Chemistry academic achievements between the XI grade students who have been treated with the life skills-based Chemistry Student's Worksheet and those who have not been treated with the life skills-based Chemistry Student's Worksheet in the 2006/2007 Academic Year if the preliminary knowledge is statistically controlled.

\section{METHOD}

The study was a research and developed that had been directed toward the development of a product in the form of learning media. The product that had been developed was a life skills-based student's worksheet for minor chemical industries. The development model of this study was adapted from the model that had been developed by Borg \& Gall (1983, p. 775) which consisted of ten stages namely: (1) research and information collecting; (2) planning; (3) preliminary product form developing; (4) preliminary field testing; (5) main product revising; (6) main field testing; (7) operational product revising; (8) operational field testing; (9) final product revising; and (10) disseminating and implementing.

On the contrary, this developmental study of life skills-based student's worksheet for minor chemical industries consisted of four stages namely: preliminary study, planning, product design, and product validation. The developmental procedures of the student's worksheet followed the procedures that would be displayed in Figure 1:

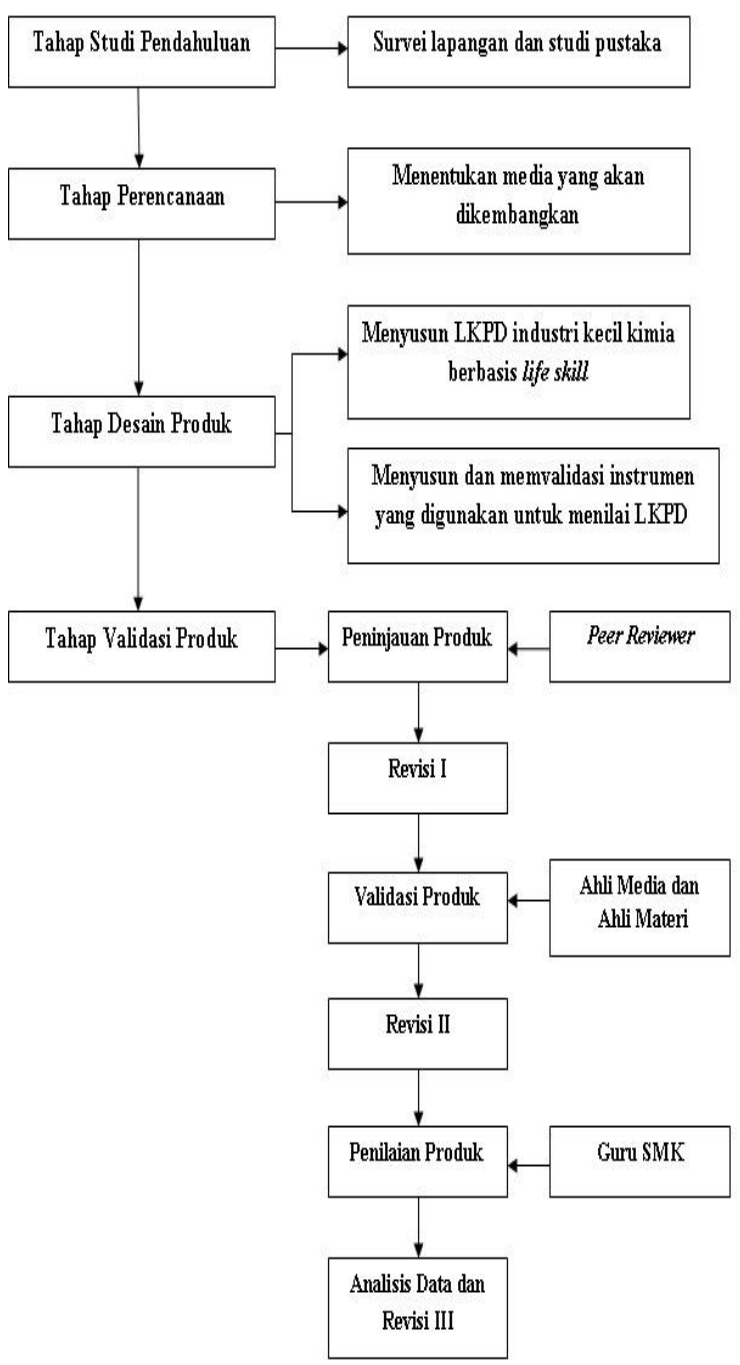

Figure 1. The Procedures of Research and Development for the Life Skills-Based Student's

Worksheet for Minor Chemical Industries

The preliminary study consisted of two sub-stages namely field survey and literature study. The field survey was conducted in order to attain information regarding the field facts and conditions of learning process. On the other hand, the literature study was conducted in order to attain any information regarding the needs that would be associated to the product development; the product itself would the learning media that would be resulted in accordance to the curriculum. In the planning stage, the researcher analyzed the existing learning media before she decided which learning media that would be developed. Furthermore, the design stage consisted of: (1) designing life skills-based student's worksheet for minor chemical industries that might be useful for improving the students' process skills and scientific attitudes; and (2) validating the instrument that might be implemented for assessing the student's work- 


\section{Jurnal Inovasi Pendidikan IPA, 3 (1), 2017 - 36}

Devita Cahyani Nugraheny

sheet. Last but not the least, the validation stage consisted of several sub-stages namely: (1) peer review toward the life skills-based student's worksheet for minor chemical industries in order to gather suggestions; (2) revision based on suggestions that had been gathered by the peer reviewer; (3) validation toward life skills-based student's worksheet for minor chemical industries by media or material experts in order to gather suggestions; (4) revision based on the suggestions that had been gathered by the media or material expert; (5) quality assessment and feedback of the life skills-based student's worksheet for minor chemical industries that the teachers had designed; (6) revision based on the suggestions that had been provided by the vocational high school teachers; and (7) analysis of the data that had been gathered from the study.

\section{Data, Instrument, and Data Gathering Technique}

The instrument that had been implemented in the assessment of life skillsbased student's worksheet for minor chemical industries was validation sheets. There were three aspects that had been referred to in conducting the worksheet assessment, namely content, language and graphics. Each aspect was elaborated into several indicators, which might be viewed in Table 1 . The criteria on the quality of the resulted worksheet then were elaborated into Very Good (VG), Good (G), Moderately Good (MG), Poor (P), and Very Poor (VP).

Table 1. Guidelines on the Instrument of Life Skills-Based Student's Worksheet for Minor Chemical Industries Quality Assessment

\begin{tabular}{lc}
\hline \multicolumn{1}{c}{ Aspects } & Number of Indicators \\
\hline Contents & 4 \\
Language & 5 \\
Graphics & 2 \\
\hline
\end{tabular}

Each aspect was elaborated into several indicators. The details of the indicators on the aspect of content were: (1) the appropriateness of content between the worksheet and the life skills; (2) the appropriateness between the activities and the objectives; (3) the emphasis on the process skills development; and (4) the emphasis on the scientific attitudes development. Next, the details of the indicators on the aspect of language were: (1) the relationship between the language and the students' understanding; (2) the relationship between the language and the meaning; (3) the pronunciation standards and accuracy; (4) the consistence of terms use; and (5) the use of foreign/scientific terms. Last but not the least, the details of the indicators on the aspect of language were: (1) the writing typography; and (2) the appropriateness between the illustration and the materials.

The data regarding the quality of the product that had been resulted from this study were presented in the form of score table on the worksheet quality and the explanation on the suggestion. The suggestions that had been provided by the vocational high school teachers were summarized and were turned into the basis for revising the student's worksheet that had been developed.

\section{Data Analysis Technique}

This study made use of descriptive data analysis with the following steps. First, the qualitative data that had been attained from an assessment by three teachers were changed into the quantitative data under the requirements that had been displayed in Table 2 .

Table 2. Score Requirements

\begin{tabular}{lc}
\hline \multicolumn{1}{c}{ Category } & Score \\
\hline VG (Very Good) & 5 \\
G (Good) & 4 \\
M (Moderate) & 3 \\
P (Poor) & 2 \\
VP (Very Poor) & 1 \\
\hline
\end{tabular}

Second, all of the data that had been attained in each aspect for each assessment indicator that had been available in the assessment instrument were tabulated. Third, the average scores of each aspect were calculated by using a formula that had been adapted from Sudjana (2002, p. 67).

$\bar{y}=\frac{\sum y}{n}$

Note:

$\bar{y}=$ average score

$\sum y=$ total score

$n \quad=$ number of rater

Fourth, the average scores were changed into the qualitative scores under the criteria of five-scale assessment category that had been adapted by Sudijono (2005, p. 175) and Supratiknya (2012, p. 158), which might be viewed in Table 3.

These qualitative scores implied the quality of the student's worksheet that had been developed. The life skills-based student's 
Jurnal Inovasi Pendidikan IPA, 3 (1), 2017 - 38

Devita Cahyani Nugraheny

Table 4. List of Student's Worksheet Title

\begin{tabular}{|c|c|c|}
\hline No. & Title & Sub-Title \\
\hline \multirow[t]{5}{*}{1.} & Aloe Vera & Aloe Vera Flour \\
\hline & Flour & The Nutrition Content of Aloe Vera \\
\hline & & The Use of Aloe Vera Flour \\
\hline & & The Process of Making Aloe Vera \\
\hline & & cal \\
\hline \multirow{3}{*}{2.} & Aloe Vera & Aloe Vera Scrub \\
\hline & Scrub & The Use of Aloe Vera Scrub \\
\hline & & $\begin{array}{l}\text { The Process of Making Aloe Vera } \\
\text { Scrub }\end{array}$ \\
\hline \multirow[t]{3}{*}{3.} & Aloe Vera & Aloe Vera Tea \\
\hline & Tea & The Use of Aloe Vera Tea \\
\hline & & The Process of Making Aloe Vera Tea \\
\hline \multirow[t]{5}{*}{4.} & Soya Bean & Soya Bean Flour \\
\hline & Flour & The Nutrition Content of Soya Bean \\
\hline & & Flour \\
\hline & & The Use of Soya Bean Flour \\
\hline & & $\begin{array}{l}\text { The Process of Making Soya Bean } \\
\text { Flour }\end{array}$ \\
\hline \multirow[t]{5}{*}{5.} & Coconut & Coconut Water Ketchup \\
\hline & Water & The Nutrition Content of Coconut \\
\hline & Ketchup & Water \\
\hline & & The Use of Coconut Water Ketchup \\
\hline & & $\begin{array}{l}\text { The Process of Making Coconut } \\
\text { Water Ketchup }\end{array}$ \\
\hline \multirow[t]{4}{*}{6.} & Chili & Chili Sauce \\
\hline & Sauce & The Nutrition Content of Chili \\
\hline & & The Use of Chili Sauce \\
\hline & & The Process of Making Chili Sauce \\
\hline
\end{tabular}

Each title in the student's worksheet contains the ingredients and the product processing directions. The product processing directions contained the product processing steps, the observation table, the questions and the assignment. The product processing activities guide the students to develop their process skills. This statement is supported by a study by Widayanto (2011). The results of his study showed that the higher the students' involvement in the laboratory practice is the higher their achievement on understanding and process skills will be.

Scientific process skills refer to a set of complex capabilities that are usually used by scientists to perform scientific investigation into the sequence of learning process. Learning process is designed to provide more opportunities for the learning participants to find facts, to define concepts, and to find new values through the process of imitating what the scientists usually do. Thereby, the students are educated and are trained to be skillful in attaining and processing information through thinking activities by following scientific (methods) procedures (Haryono, 2006, p. 2). The process skills that have been developed during the product processing activities are observation, experiment, and communication skills.

Bundu (2006, pp. 23-24) explained the characteristics of process skills-related activities. These skills are related to the students' observation skills when they use their five senses to observe and to gather the necessary data. In conducting the observation, the students operate aides in order to perform more detailed observation and measurement or to do comparison with more appropriate aides.

Experimental skills refer to the activities that include all process skills. The experimental skills covers deciding tools and materials that will be used, deciding the objects that will be observed, deciding the objects that will be measured, deciding the activity steps, and deciding how the data will be manipulated and be inferred.

Communication skills might be oral and written. The students' oral communication skills might be trained through the provision of group assignment that deals with the discussion of observation results and question answering activities and that presents the results of group discussion that has been conducted. On the other hand, the students' written communication skills might be trained through the submission of product processing report by each student.

Besides being the part of process skills, product processing directions in the student's worksheet might also lead the students to develop scientific attitudes. This statement is supported by a study by Hayat et al. (2011), which concluded that laboratory practice-based learning process has positive and more effective impact in developing the students' scientific attitudes. The scientific attitudes that might be developed through the product processing activities are disciplined, careful, honest, responsible, open minded, and cooperative. The contents of the student's worksheet might encourage the students to be punctual and be responsible through the existing requirements in the product processing directions. The steps in the product processing activities lead to the development on the attitude of being careful, such as the attitude of being careful in performing observation and measurement. Developing the attitude of being honest among the students might be performed by providing space for writing the data that are in accordance to the observation results. The attitude of being open minded and cooperative might be developed through the product processing 
activities that follow the existing steps, the assignment of group discussion for discussing the experiment results, and the presentation of the discussion results.

Based on the assessment that had been attained from three vocational high school teachers and the analysis technique that had been implemented, the assessment results were tabulated into Table 5 .

Table 5. Quality Assessment Results of the Life Skills-Based Student's Worksheet for Minor Chemical Industries

\begin{tabular}{lrrr}
\hline \multicolumn{1}{c}{ Aspect } & $\begin{array}{c}\text { Mean } \\
\text { Score }\end{array}$ & $\begin{array}{c}\text { Maximum } \\
\text { Mean Score }\end{array}$ & Category \\
\hline Content & 18.00 & 20.00 & Very Good \\
Language & 21.20 & 25.00 & Very Good \\
Graphics & 8.20 & 10.00 & Very Good \\
\hline
\end{tabular}

Based on the results of the student's worksheet assessment in all aspects (content, language, and graphics), the worksheet fell into the "Very Good" category; as a result, the life skills-based student's worksheet for minor chemical industries might be feasible for the implementation of the learning process. The resulted student's worksheet has several advantages and the advantages are providing direct experience to the students and inviting the students to develop their process skills and scientific attitudes through the product processing activities. The results of quality assessment for every aspect in the worksheet were presented in diagram on Figure 2.

All of the assessment aspects for the worksheet fell into the "Very Good" category, although the percentage of achievement in each aspect was different. Based on the diagram of student's worksheet quality assessment on Figure 2, the researcher might conclude that the aspects of content earned the highest score. The percentage of achievement for the aspects of content was $90.00 \%$. On the contrary, the lowest percentage of achievement was attained by the aspects of graphics, namely $82.00 \%$.

The assessment results for the aspects of content in the student's worksheet fell into the "Very Good" category. These results imply that: (1) the learning materials and activities in the student's worksheet have been based on the life skills; (2) the learning materials and activities in the student's worksheet have been in accordance to the activity objectives; (3) the learning materials and steps in the student's worksheet have been able to develop the students' process skills; and (4) the learning materials and steps in the product processing activities might develop the students' scientific attitudes.

The assessment results for the aspects of language in the student's worksheet fell into the "Very Good" category. These results imply that: (1) the language in the student's worksheet has been easy to be understood by the students; (2) the language that has been used does not trigger bias interpretation; (3) the language that has been used is standardized and makes of appropriate pronunciation; (4) the language that has been used is consistent in terms of terminology composition from one section in the student's worksheet to another; and (5) the language that has been used in consistent in terms of scientific or foreign terminology composition from one section in the student's worksheet to another.

The assessment results of the aspects of graphics ell into the "Very Good" category. These results imply that: (1) the writings might be read well and make use of less than three types of combination between forms and writings; and (2) the illustrations that have been used in the student's worksheet is already in accordance to the materials that have been presented.

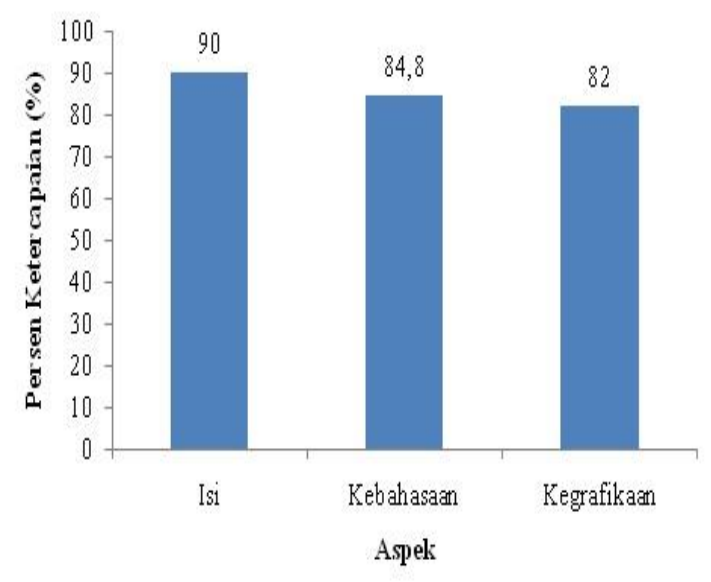

Figure 2. Diagram of the Student's Worksheet Quality Assessment Results

\section{CONCLUSIONS}

Based on the results of the study, the researcher would like to conclude that: (1) the product that has been resulted is the life skillsbased student's worksheet for minor chemical industries; and (2) the results of assessment that has been conducted by the Chemistry teachers in the vocational high school show that in average the student's worksheet has fallen into the "Very Good" category. Therefore, the life skills-based student's worksheet for minor chemical 
industries is feasible for learning process implementation.

\section{REFERENCES}

Akinbobola, A. O., \& Afolabi, F. (2010). Analysis of science process skills in West African senior secondary school certificate physics practical examinations in Nigeria. Bulgarian Journal of Science and Education Policy (BJSEP), 4(1), 32-47. Retrieved from http://bjsep.org/getfile.php?id=64

Anonim. (2010). Apa itu sikap ilmiah? Retrieved June 10, 2017, from http://wartawarga.gunadarma.ac.id/2010/0 3/apa-itu-sikap-ilmiah/

Arsyad, A. (2002). Media pembelajaran. Jakarta: RajaGrafindo Persada. http://doi.org/2002

Borg, W. R., \& Gall, M. D. (1983). Educational research: An introduction. New York: Longman.

Bundu, P. (2006). Penilaian keterampilan proses dan sikap ilmiah dalam pembelajaran sains SD. Jakarta: Depdiknas RI.

Devi, P. K., Sofiraeni, R., \& Khairuddin, K. (2009). Pengembangan perangkat pembelajaran untuk guru SMP. Bandung: Pusat Pengembangan dan Pemberdayaan Pendidik dan Tenaga Kependidikan Ilmu Pengetahuan Alam. Retrieved from https://mgmpmatsatapmalang.files.wordpre ss.com/2012/07/pengembanganperangkats mp.pdf

Handayani, S. (2009). Muatan life skill dalam pembelajaran di sekolah upaya menciptakan sumber daya manusia yang bermutu. In Prosiding Konferensi Internasional Pendidikan, UPI-UPISI di Malaysia. Bandung: Universitas Pendidikan Indonesia.

Harahab, D. P., Raharjo, R., \& Kuswanti, N. (2012). Pengembangan LKS berorientasi kecakapan hidup (life skill) untuk SMA kelas XI pada materi sistem peredaran darah manusia. BioEdu, 1(2), 28-30. Retrieved from http://jurnalmahasiswa.unesa.ac.id/index.p $\mathrm{hp} /$ bioedu

Haryono, H. (2006). Model pembelajaran berbasis peningkatan keterampilan proses sains. Jurnal Pendidikan Dasar, 7(1).
Retrieved from https://hierofredy.files.wordpress.com/201 2/01/model_pembelajaran_berbasis_penin gkatan_ketrampilan_proses_sains.pdf

Hayat, M. S., Anggraeini, S., \& Redjeki, S. (2011). Pembelajaran berbasis praktikum pada konsep invertebrata untuk pengembangan sikap ilmiah siswa. Bioma, 1(2).

Khoiri, N., Hindarto, N., \& Sulhadi, S. (2011). Pengembangan perangkat pembelajaran fisika berbasis life skill untuk meningkatkan minat kewirausahaan siswa. Jurnal Pendidikan Fisika Indonesia, 7, 8488. Retrieved from https://journal.unnes.ac.id/nju/index.php/JP FI/article/viewFile/1077/987

Menteri Pendidikan Nasional. Peraturan Menteri Pendidikan Nasional RI nomor 22, tahun 2006, tentang standar isi intuk satuan pendidikan dan menengah, Peraturan Menteri Pendidikan Nasional (2006).

Nurharjadmo, W. (2008). Evaluasi implementasi kebijakan pendidikan sistem ganda di sekolah kejuruan. Spirit Publik, 4(2), 215228. Retrieved from http://webfisip.fisip.uns.ac.id/journal/sp4_ 2_wahyu.pdf

Patil, G. V. (2011). A comparative study os scientific attitude about secondary and higher secondary level students. International Referred Research Journal, II.

Pitafi, A. I., \& Farooq, M. (2012). Measurement of scientific attitude of secondary school students in Pakistan. Academic Research International, 2(2), 379-392. Retrieved from www.savap.org.pk

Prastowo, A. (2011). Panduan kreatif membuat bahan ajar inovatif. Jogjakarta: DIVA Press.

Pusat Kurikulum Balitbang Depdiknas. (2006). Pengembangan model pendidikan kecakapan hidup. Jakarta: Departemen Pendidikan Nasional.

Rohaeti, E., Widjajanti, E., \& Padmaningrum, R. T. (2009). Pengembangan lembar kerja siswa (LKS) mata pelajaran sains kimia untuk SMP. Jurnal Inovasi Pendidikan, 10(1). Retrieved from http://jurnal.fkip.uns.ac.id/index.php/jip/art icle/view/479 


\section{Jurnal Inovasi Pendidikan IPA, 3 (1), 2017 - 41}

Devita Cahyani Nugraheny

Senam, S., Arianingrum, R., Permanasari, L., \& Suharto, S. (2008). Efektivitas pembelajaran kimia untuk siswa kimia kelas XI dengan menggunakan LKS kimia berbasis life skill. Jurnal Pendidikan Didaktika, 280-290.

Sudijono, A. (2005). Pengantar statistik pendidikan. Jakarta: PT Raja Grafindo Persada.

Sudira, P. (2006). Kurikulum tingkat satuan pendidikan SMK. Jakarta: Departemen Pendidikan Nasional.

Sudjana, S. (2002). Metode statistika. Bandung: Tarsito.

Sukmadinata, N. S. (2013). Metode penelitian pendidikan. Bandung: PT Remaja Rosdakarya.

Supratiknya, A. (2012). Penilaian hasil belajar dengan teknik nontes. Yogyakarta: Universitas Sanata Dharma.

Toharudin, U. (2011). Membangun literasi sains peserta didik. Bandung: Humaniora. http://doi.org/2011

Trianto, T. (2010). Mendesain model pembelajaran inovatif-progresif: konsep, landasan, dan imlementasinya pada kurikulum tingkat satuan pendidikan (KTSP). Jakarta: Kencana.

Widayanto, W. (2011). Pengembangan keterampilan proses dan pemahaman siswa kelas X melalui kit optik. Jurnal Pendidikan Fisika Indonesia, 5(1). http://doi.org/10.15294/jpfi.v5i1.991

Widiaty, I. (2013). Relevansi kurikulum SMK berbasis industri kreatif dengan metode extrapolation and the econometric approach. Innovation of Vocational Technology Education, 9(1). http://doi.org/10.17509/invotec.v9i1.4882

Widjajanti, E. (2008). Pelatihan penyusunan LKS mata pelajaran kimia berdasarkan kurikulum tingkat satuan pendidikan bagi guru SMK/MAK. Yogyakarta: Fakultas Matematika dan Ilmu Pengetahuan Alam Universitas Negeri Yogyakarta.

Yuliati, Y., Umniyatie, S., \& Setyaningsih, W. (2008). Pelatihan implementasi "life skill", pada pembelajaran IPA-Biologi melalui kegiatan pembuatan LKS model empirik bagi guru SMP di Kabupaten Bantul DIY. Yogyakarta. 